\title{
Towards a New Academic Discipline of Family Sciences
}

\author{
INGEBORG SCHWENZER* and SABINE AESCHLIMANN**
}

\section{Introduction and Factual Background}

During the last forty years, demographic data have undergone profound changes throughout western industrialised countries. Subject to minor time lags, the developments occurring in society have been surprisingly uniform.

The most salient feature is the rising divorce rate. In many countries, the probability of divorce has now reached 40 to 50 per cent. The development in Scandinavia, however, where a certain stagnation at this high level has been observed since the 1980 s, shows that the saturation point might now have been reached. The high number of divorces brings about manifold further developments. These are, on the one hand, the rapid increase of children living in stepfamilies and, on the other hand, the growing number of single-parent families. This again is closely linked to the phenomenon described generally as the "feminisation of poverty". Studies on poverty have shown that, in many countries, divorce constitutes a much higher risk factor for women than for men. ${ }^{1}$

Developments parallel to the increasing divorce rate are the increase in age at first marriage and the general decrease in marriages. Taking the example of France, this means that today approximately 41 per cent of all women below the age of fifty remain unmarried, compared to approximately 92 per cent of all women of this group in 1979 who married at least once in their lives. ${ }^{2}$

Concurrently, cohabitation has increased in all countries, in some places indeed dramatically. In the Scandinavian countries, cohabitation can be considered as an actual alternative to marriage, whereas in many other countries, extra-marital

\footnotetext{
* Dr. iur., LL.M. (UC Berkeley), Professor of Private Law, Law Faculty of the University of Basel, Switzerland; President of the Center for Family Sciences.

** lic. iur., LL.M., Attorney at Law, Academic Assistant, Law Faculty of the University of Basel, Switzerland.

1 Compare for Switzerland: Leu et al., Lebensqualität und Armut in der Schweiz, 1997; Canada: Diduck/Orton, „Equality and Support for Spouses“, 57 MLR 1994, 684 et seq.; Australia: Sifris, Australia, 14 AFL 2000, 1, 3.

2 Compare Council of Europe, Recent Demographic Developments in Europe, Strasbourg, 2003 at T2.2.
}

International Law FORUM du droit international 7: 178-185, 2005.

(C)2005 Koninklijke Brill N.V., Leiden, The Netherlands. 
unions are of shorter duration, as they are frequently formalised based on a pattern of child-orientated marriage. ${ }^{3}$

With regard to the number of births, a general decline in fertility rates can be observed. Since about 1965 , the reproduction rate of the population has fallen to a below-replacement level in all developed countries. ${ }^{4}$ On the other hand, the number of out-of-wedlock births has increased dramatically over the last decades. In some countries, namely of the Scandinavian region, it has reached a level of between 50 and 65 per cent. ${ }^{5}$

These developments imply new challenges for research, practice, and education of professionals in disciplines dealing with family matters. This necessary new approach may be summariszed as the emerging field of "family sciences". The characteristics of family sciences are: internationality, interdisciplinarity and permeability between research and practice.

\section{Internationality}

As shown above, all these developments concerning the family have not been confined to one or even some countries, but may be called universal.

In social sciences, there was never any doubt that a national psychology, sociology, anthropology or the like does not exist. Thus, for decades, the leading journals in these fields have appeared in English ${ }^{6}$ and all relevant articles are accessible through a world-wide system such as, for instance, sociological abstracts. ${ }^{7}$ In contrast, the situation in the field of law regarding internationality looks rather different. A great amount of effort is still necessary in order to catch up with the social sciences.

Up to the 1960s, family law was mostly a national affair. It was assumed that family law was nothing but a mirror of societal value judgements. These in turn did indeed considerably differ from country to country. Thus, it was held that there would be no sense in comparing the solutions of different family law systems.

3 Compare for Germany: Nave-Herz, Familiale Veränderungen in der Bundesrepublik Deutschland seit 1950, ZSE 1984, 45 et seq.

4 Compare Rothenbacher, "Social Change in Europe and its Impact on Family Structures" in: J. Eekelaar/Nhlapo (Eds.), The Changing Family, Oxford, 1998, 3, 5.

5 In 2002: Norway 50.3 per cent, Denmark 44.6 per cent, Iceland 62.3 per cent: Council of Europe, Recent Demographic Developments in Europe, Strasbourg, 2003 at T3.2.

6 Annual Review of Sociology, Berlin Journal for Sociology, American Journal for Sociology, Canadian Journal for Sociology, Acta Psychologica, American Antropologist etc.

7 E.g., Cambridge Sociological Abstracts, http://www.csa.com/factsheets/socioabs-setc.php. 
This situation started to change in the 1970s. One of the pioneers was Max Rheinstein, who in his famous book "Marriage, Stability and Divorce", ${ }^{8}$ began to compare the seemingly incomparable law and practice of separation and divorce in such different countries as the United States, Japan, Sweden, the Soviet Union and Italy, a country that did not allow legal divorce at all in those days. This was the emergence of comparative family law, soon culminating in the founding of the International Society of Family Law. ${ }^{9}$ Whereas the necessity and utility of comparative family law is nowadays no longer contested, the idea that family law may be unified on a larger scale is relatively new. ${ }^{10}$ The movement of elaborating uniform principles that emanated from the law of obligations did not reach the field of family law until 2001, when the Commission on European Family Law was established. ${ }^{11}$ The Commission has published principles on the grounds for divorce, as well as on maintenance between former spouses. ${ }^{12}$

Even if family law may be harmonised by relying on uniform principles in $\mathrm{Eu}$ rope, important tasks remain for the comparative legal aspects of family sciences.

Firstly, family sciences should not be confined to the law as it is found in the principles or in books, but it must also reveal the law as it appears in action. Especially in family law, the latter often differs considerably from the black letter rules and one and the same notion may be interpreted in completely different ways in different countries.

Secondly, family sciences cannot - when propagating new solutions - ignore the experiences gained from a certain legal rule in foreign countries. Thus, it could be observed world-wide that the implementation of no-fault divorce led to a decrease in maintenance orders for divorced women, this in turn being responsible for the already mentioned feminisation of poverty. Although this fact was well known from the experience in the U.S. since the late $1970 \mathrm{~s},{ }^{13}$ legislation in other countries did not take it sufficiently into account. Similar developments may be noted in the field of parental responsibility after divorce, where nowadays continuing joint custody appears to be the rule in almost all legal systems. In all these countries, conflicts

8 Rheinstein, Marriage Stability, Divorce and the Law, Chicago/London, 1972.

9 http://www.law2.byu.edu/isf/.

10 See Schwenzer, Die Europäisirung des Familienrechts, in: Sutter-Somm/Schnyder (Eds.), Festgabe für Franz Hasenböhler, Zürich/Basel/Genf, 2004, 25 - 42.

" hrtp://www2.law.uu.nl/priv/cefl/.

12 Organising Committee of the Commission on European Family Law, Principles of Family Law Regarding Divorce and Maintenance Between Former Spouses, Antwerp/Oxford, 2004.

13 Weitzman, The Divorce Revolution, New York, 1985. 
regarding access and visitation are increasing, an issue that still awaits thorough comparative analysis.

Thirdly, the scope of comparative family law still appears to be rather limited. Besides the European legal systems which are the focus of the Commission on European Family Law, regular comparison is only made with U.S. law. However, the most modern and elaborate solutions in family law nowadays are often found in the law of the Canadian provinces, Australia and its states and territories, and New Zealand. Family science in a broad sense has to continuously keep an eye on these developments and consider their potential as a model for the best solution of family conflicts.

\section{Interdisciplinarity}

\section{Necessity}

Interdisciplinarity may be said to be the most important characteristic of an academic discipline of family sciences. Human behaviour and occurring phenomena associated with familial ways of living cannot comprehensively be explained or even understood by a one-sided view from the perspective of a single science; rather, aspects of different disciplines have to be considered to achieve a more holistic understanding.

A well known and early advocate of a multidisciplinary approach is Gary Becker whose work extends over a large number of disciplines including economics, sociology, psychology, and biology. As early as half a century ago, in his doctoral dissertation on the economics of discrimination, Becker scrutinised the traditional division of labour between sociology and economics. ${ }^{14}$ As a major contribution, Becker developed the "new home economics" in the U.S. In applying economic tools to social issues, traditionally considered beyond the domain of economists, Becker's work contributed to a better understanding of a wide range of individual behaviour, such as marriage, divorce and fertility. ${ }^{15}$

In the field of family law, the need for an interdisciplinary exchange was also perceived and postulated, particularly by Goldstein/Freund/Solnit in their book "Beyond the Best Interests of the Child" ${ }^{16}$ The authors emphasised that, especially in child law, psychological knowledge is essential to creating legal rules promoting "the best interest of the child" as the paramount principle in this area. In their book, they particularly outlined the considerable difference between children and

14 Becker, The Economics of Discrimination, 2nd ed. Chicago, 1971.

15 E.g. Becker, The Economic Approach to Human Behaviour, Chicago 1976; or Becker, A Treatise on the Family, 2nd ed. Cambridge, 1991 (1st ed. 1981).

16 Goldstein/Freud/Solnit, Beyond the Best Interests of the Child, New York, 1973. 
adults regarding the conception of time. This, as well as some other major findings identified in their work, subsequently influenced the substantive and the procedural law concerning children. ${ }^{17}$ Modern problems such as the so-called parental alienation syndrome (P.A.S.) or the questions surrounding international child abduction are two recent examples which demonstrate that psychological knowledge is absolutely essential when striving for appropriate solutions for children.

Likewise, an effective family policy depends on a holistic comprehension of the occurring phenomena based on an interdisciplinary approach. For example, the realisation of the political aim to safeguard further generations requires a comprehensive understanding of the phenomenon of the decreasing birth rate. ${ }^{18} \mathrm{~A}$ comparison between European states shows that the lowest fertility rates are often associated with those countries that have a greater difference between men and women with respect to employment. ${ }^{19}$ In Europe, for instance, Norway has - besides Iceland and Ireland - the highest fertility rate ( 1.93 children) and at the same time the highest percentage of women that are gainfully employed (75.3\%). Spain figures at the far end of the European spectrum, with only 48 per cent employed women and an average of 1.25 children. ${ }^{20}$ These data suggest that higher fertility rates are directly linked to better conditions of the compatibility of work and family life. Furthermore, the examples of Scandinavian countries show the efficiency of models in which family policy is strongly shaped by the aim to modernise gender roles and reach gender equality, especially in the labour market. This again calls for an efficient family policy in this area to strive for solutions aimed at creating better work/life balances, particularly for partnerships with children.

Family Sciences may also be understood as a doctrine that investigates relations within the family - as well as the family within society - by dealing with questions of tax, the labour market, etc. The findings of family sciences may then form the basis for an efficient family policy. An array of disciplines, including psychology, sociology, economics, demography, gender studies, anthropology and family

17 E.g measures to ensure continuing relationships in children's life like the restricted possibility for natural parents to take back foster children, or the introduction of a counsel for the child may be mentioned as two examples of the authors' achievements.

18 E.g. Kaufmann, Familienpolitik als interdisziplinäre Herausforderung, FamPra.ch 2002, 433, 436 et seq.

19 E.g. Palomba/Kotowska, The Economic Active Population in Europe, Strasbourg, 2003, 11 et seq.

20 Compare Council of Europe, Recent Demographic Developments in Europe, Strasbourg, 2003 at T3.3. 
law, or at least parts of each, are suited to comprise the envisaged discipline. All these disciplines would meld on an overarching level and merge to the envisaged, independent academic discipline of family sciences.

A goal of the envisaged discipline will be to group and structure research findings of the various disciplines and to integrate them into the scientific system as a whole. Furthermore, a major aim is to develop strategies ensuring that the sciences involved do nor coexist independently. Rather, the scientific findings elaborated in each individual part-discipline have to be transmitted to all participating disciplines in order to allow further, internal processing in each discipline. It is precisely this integrative bundling of different disciplines, into one single interdisciplinary (and not only multidisciplinary) approach to the research subject of familial ways of living that is still in the very early stages of development. Under this interdisciplinary approach, researchers traditionally working in their respective disciplines could still have a place and function. However, a new group of scholars would have to evolve, specialising primarily in the integration of the different participating disciplines. This second group of academics would comprise the representatives of this independent academic discipline.

\section{Problems}

As set out above, interdisciplinarity in family sciences means analysing problems surrounding familial ways of living from the perspective of different disciplines, with the aim of comprehensively understanding the occurring phenomena. Realising a consistent interdisciplinary working method, however, implies considerable difficulties:

Finding one single scholar who is able to combine the proposed interdisciplinary approach withour being overstrained may be impossible. The practical realisation of the envisaged discipline of family sciences will only succeed by a close cooperation between several persons who are members from different disciplines, working together in teams. Furthermore, scholars engaged in this environment will need to be willing to familiarise themselves with basic principles of the neighbouring disciplines in order to achieve the capacity to conduct an interdisciplinary dialogue.

The communication between the various disciplines will form another difficulty en route to the envisaged interdisciplinary approach in family sciences. Each discipline involved has its own perception and particular view of the research subject, but none is able to comprehend the phenomena entirely. The focus of the individual disciplines regularly centers - depending on methods and definition of the research subject - only on certain aspects of the family and human behaviour. Already, the definition of "family" may vary in the different disciplines according to their respective focus. To find a common basis therefore requires each discipline involved to accept certain concessions concerning method, language etc.; this in turn 
will demand a high degree of mutual understanding and tolerance. Furthermore, avoiding a predominance of one participating discipline is crucial and hierarchies should not be tolerated.

To facilitate the dialogue, the creation of a common language will have to be considered. Similar to comparative law, a promising method may be to establish an overarching language, which derives from pure disciplinary terminologies but focuses on factual issues. With regard to the scientific method suitable for the envisaged academic discipline, a confined pluralism of various methods may be admitted to investigate appearing phenomena. Thus, it would be an aim to make one method profitable for the use of another. ${ }^{21}$

A functioning interdisciplinary dialogue - in which criticism concerning the various disciplines is also allowed - promises benefits and improvements for each participating discipline. However, it has to be kept in mind that disciplinarity must form the basis of interdisciplinarity. Accordingly, an interdisciplinary approach of high quality presupposes extensive and solid knowledge in the own discipline. ${ }^{22}$

The establishment of the envisaged independent scientific discipline of family science, developed by the described approach, requires interdisciplinary courses, programs and degrees which are offered on a secondary educational level, following a mono-disciplinary education on a first level. This may be implemented by interdisciplinary postgraduate courses, for instance by the introduction of a Master of Family Sciences; or further, by implementing joint research projects for young researchers originating from different disciplines.

\section{Permeability between research and practice}

The real-life situation of families is predominantly influenced by practitioners (the judiciary, social workers, psychiatrists, psychologists, lawyers, the administration etc.). This practical knowledge must be included in academic reflection and form its basis. Pure scholarly research runs the risk of being entangled in terminologies and work in an ivory tower with little reference to practical problems affecting family life. Practice, on the other hand, is generally focused on individual cases without the ability to abstract and generate general theories. Both research and practice therefore have their own specific function in the field of family sciences and it is crucial to establish an active cooperation in order for both to mutually profit and develop further.

${ }^{21}$ Wingén, Auf dem Weg zur Familienwissenschaft, Vorüberlegungen zur Grundlegung eines interdisziplinär angelegten Fachs, Berlin, 2004, note 21, 45.

22 Similar: Fede, Was deutschen Universitäten an Reformunfug blüht: Hamburg als Exempel, Frankfurter Allgemeine Zeitung, 7th of April 2003. 
An exchange, may for example, be achieved by selecting topics for upcoming research projects through consultation with the practice. Furthermore, conferences, public lectures, and the field of continuing education are excellent platforms to inform practitioners about the new findings and contribute to the realisation of the necessary exchange between scholars and practitioners. Peer support and supervision groups have also become well-known over the last years and these give practitioners a chance to reflect on their work, often under the supervision of scholars, and are thus a means to contribute to this aim.

\section{Conclusion}

In order to cope with the fundamental changes in society over the last decades, it is necessary to establish a new academic discipline that may be summarised as "family sciences". Internationality, interdisciplinarity, as well as permeability between research and practice, characterise this new approach. However, the academic discipline of family sciences is still in its infancy. At this stage, Universities hold a key position. Accepting the permeability of the borders of the single disciplines involved in family sciences and allowing an interdisciplinary exchange as well as the introduction of chairs of family sciences ${ }^{23}$ may be two measures that could contribute significantly to the establishment of the envisaged academic discipline. A convincing solution of pending tasks may subsequently help gain broad recognition for this new discipline. However, more efforts are necessary and many hurdles have to be overcome before the aim of an over-riding academic discipline of family sciences will be achieved.

23 A first step in this direction was made at the University of Erfurt where the first world-wide chair of family sciences was established in 2002; also see Wingen, Ein bedeutsamer Schritt auf dem Wege zu eine eigenständigen Fachdisziplin Familienwissenschaft, ZfF 2002, 167 et seq. 